\title{
The Committee for Cultural Freedom AND the RoOTS OF McCarthyisM
}

\author{
Gary B. Bullert
}

\section{Abstract}

Among the most controversial aspects of John Dewey's career as a public intellectual was his conflict with the Communist Party and its various front groups. John Dewey and Sidney Hook co-founded the Committee for Cultural Freedom that directly exposed that pretense of the Popular Front, which excluded the Soviet Union from the list of totalitarian states. In the process, Dewey became embroiled publicly with Corliss Lamont and privately (to a large degree) with Franz Boas. Besides policy toward the Soviet Union, the New York Teachers' Union's decertification emerged as a central issue. In the process, Dewey exhibited both intellectual integrity and courage by opposing threats to both academic freedom and the democratic process.

Founded on May 14, 1939 by John Dewey and Sidney Hook, the Committee for Cultural Freedom (CCF) has been acknowledged as the most formidable antiStalinist liberal organization. Its first public statement of principles endeavored to demarcate the salient incommensurable conflict between democratic and totalitarian societies. Amidst a political climate, particularly in New York City, where Communist influence reached its zenith, the CCF dissected the core premise of the Popular Front by naming the Soviet Union a totalitarian state. It proclaimed that, "in fear or despair they [Crypto-Stalinists] hasten to exalt one brand of intellectual servitude over another; to make fine distinctions between various methods of humiliating the human spirit and outlawing intellectual integrity. Many of them have already declared a moratorium on reason and creative freedom. Instead of resisting and denouncing all attempts to straitjacket the human mind, they glorify under deceptive slogans and names, the color and the cut of one straightjacket rather than another."' The Popular Front press and Communist Party operatives initiated a relentless campaign to destroy and discredit the Committee for Cultural Freedom; a campaign that is still advanced by post-New Left historians. Exhuming the genesis of McCarthyite "red baiting," Ellen Schrecker held that understanding the fate of Communist teachers in the fifties mandated an analysis of what transpired in the thirties. ${ }^{2}$ Was the Committee for Cultural Freedom to be blamed for sowing division within the Left or were the Communist Party tactics of deceit, obstructionism, 
and castigating social democrats as fascists the real culprit? Sidney Hook has been routinely ostracized in these historical narratives. In contrast to the more gentle and permissive John Dewey, Hook has been accused of disingenuously manipulating John Dewey as a means of implementing his own vindictive, clandestine agenda. Other accounts target the Committee for Cultural Freedom and Dewey himself for undermining the Popular Front with the sole mission of sabotaging Franz Boas' highly successful American Committee for Democracy and Intellectual Freedom (ACDIF). ${ }^{3}$ Was the CCF portrayal of the Communist Party overstated in a manner that offered a veneer of scholarly respectability for sinister waves of red-scare hysteria? For example, Andrew Feffer concluded, "Dewey's legacy in the 1930s for the repressive anti-communism of the 1940s and 1950s should be obvious: while it is true that Dewey's investigation was informed in large part by a moderate socialism that guided his politics in the 1930s, it nonetheless anticipated many of the conventions of later anti-communist crusades. ${ }^{\text {"4 }}$ By situating the CCF within its historical-geographical milieu, the viability of these allegations can be realistically scrutinized.

I.

A subtext for this analysis considers the professional-personal relationship of four prominent New York public intellectuals: John Dewey, Franz Boas, Corliss Lamont, and Sidney Hook. First, Sidney Hook did not cajole Dewey into embracing a militant anti-Communist profile. Despite Dewey's initial enthusiasm for the Soviet experiment, by 1932-33, he became an outspoken opponent of the Communist Party both in the United States and abroad. In 1933, Dewey chaired a committee investigating communist obstructionism and subversion within the New York Teachers Union. Before 800 teachers at a public meeting, Dewey recommended that six teachers be expelled, including Isador Begun who served as a New York state Communist Party official. Despite Dewey's concerted effort to be conciliatory and admittedly permissive (a six-month suspension for one of the defendants, Clara Lieber), the Union failed to suspend them for a lack of two-thirds vote of the membership. ${ }^{5}$ The Union leadership, with Dewey's support, petitioned the American Federation of Teachers to rewrite the charter in order to prevent Communist Party members from subverting the union in order to promote the political agenda of the Soviet Union. When this failed, Dewey, along with 650 other Union members, resigned and formed a new organization, the New York Teachers Guild. ${ }^{6}$ The controversy of Communists as teachers would fester for decades and embroiled, most notably, Sidney Hook.

In 1934, Communist Party hooligans broke up a Socialist Party rally at Madison Square Garden. ${ }^{7}$ In a letter to Roger Baldwin, head of the American Civil Liberties Union, Dewey declared that he agreed entirely with Norman Thomas in blaming the Communists and further insisted that Communist Party members 
be banned from leadership positions in the ACLU. ${ }^{8}$ Disgusted by these ongoing tactics, Norman Thomas advocated that Communist Party members employed as teachers be fired. ${ }^{9}$ While Sidney Hook was still identifying himself as a communist, Dewey explained that "as an unalterable opponent of Fascism in every form, I cannot be a Communist." ${ }^{10}$ In the same symposium, Hook acknowledged the Nazi-Communist alliance in Germany helped to facilitate the destruction of the Weimar Republic. The Comintern specifically prioritized the Social Democrats as class enemies and referred to them as "social fascists." As early as 1937, Dewey predicted a similar totalitarian alliance-the Nazi-Soviet Pact. Hook soon recognized that his promotion of "communism without dogmas" was supplanted in practice by the infallibility of the Party.

When Stalin executed without trial one hundred seventeen alleged assassins in the Kirov Purge (1934), Dewey wrote an open letter to the National Committee for the Defense of Political Prisoners protesting what appeared to be a blatant violation of civil liberties. ${ }^{11}$ Sidney Hook also condemned the purge. Alfred Hirsch, secretary of the NCDPP, insisted that the accused were not entitled to a legal defense. Dewey's colleague, Horace Kallen, charged that the organization was guilty of a double standard toward Stalin and the fascists. ${ }^{12}$ John Howard Lawson chastised Kallen and described the executions as "a necessary and admirable procedure."13 Corliss Lamont abstained from any criticism of the executions. However, in private letter, Franz Boas discreetly resigned from the NCDPP, but refused to implicate Stalin. ${ }^{14}$ This event established a predictable pattern for these public intellectuals: Dewey and Hook(anti-Stalinists), Corliss Lamont(devoted Soviet apologist), and Franz Boas(hybrid fellow traveler).

Despite Dewey-Boas collaboration in Popular Front causes involving antiNazism and the Spanish Civil War, the Trotsky Trial irreparably bifurcated the Stalinist from the Social Democratic wings of the Left. Dewey's acceptance as chair of the Inquiry was deemed an unpardonable offence to the Popular Front. This decision was not instigated by Sidney Hook, though he was a member of the American Committee for the Defense of Leon Trotsky, but resulted from the Communist campaign of intimidation, bribes, and character assassination (tactics with which Dewey was already well-acquainted). This reinforced Hook's resolve. ${ }^{15}$ These actions were orchestrated by the Soviet ambassador to the United States, Alexander Troyanovsky. This campaign tried to undermine the Inquiry by pressuring members to resign. In fact, several did resign, including Maurice Hallgren (an editor of the Nation) and Carleton Beals whose public statements seemed as scripted as the confessions in the Show Trials themselves. In a letter to Leon Trotsky, Suzanne LaFollette observed, "not since the War, I think has any issue so excited and divided the American intellectual world as the Moscow Trials. ${ }^{{ }^{16}}$ Dewey insisted that it wasn't Trotsky's ideology that was on trial but the specific criminal actions cited in the Moscow Trials. Attacking his colleague and former teacher, John Dewey, Corliss 
Lamont circulated an "Open Letter to American Liberals," defaming the Inquiry and alleging that it would abet fascism. ${ }^{17}$ Lamont actually debated Dewey on CBS radio. Meanwhile, Sidney Hook, who deservedly earned the moniker of "Dewey's Bulldog," published a devastating indictment of Corliss Lamont. ${ }^{18}$ Dewey personally congratulated Hook for his courage and loyalty as well as incisive polemics. ${ }^{19}$

When Franz Boas joined the American Committee for the Defense of Leon Trotsky, George Novack (committee secretary) triumphantly proclaimed to Trotsky that Boas "next to John Dewey ranks as the Dean of American liberals. ${ }^{20}$ Boas' role appeared at first to be perfunctory (no documented involvement) and then very suspicious. After the Inquiry Commission verdict of "not guilty" was announced, Dewey sought to supply the mass of documented evidence for the next round of the Show Trials, describing the earlier trials as "frame-ups." ${ }^{21}$ Within three days of the newspaper article, Boas wrote a letter to the New York Times charging that Dewey had used his name without permission. Though not reticent about events in Spain or Germany, Boas declared that he wasn't privy to knowledge about the internal affairs of the Soviet Union. ${ }^{22}$ This would not be the last occasion where Boas would place himself at the service of the current dictates of the party line. Deploying the fallback position of the New Republic and Nation, he reverted to the posture of suspension of judgment. Did Boas not read Dewey's exhaustive Inquiry findings? Dewey defended the Inquiry as being in full accord with the scientific method. Corliss Lamont deployed Boas' disclaimer in order to undermine Dewey's credibility. ${ }^{23}$ Dewey remarked that it was the "standing weakness" of many liberals not to confront honestly the discomforting reality of Stalinism. ${ }^{24}$ Since the Soviet Union was popularly portrayed as an attractive alternative model, skewing democratic discourse in the United States, it was incumbent to demystify Stalin's workers' paradise and sooner rather than later. Sidney Hook was also alarmed at the deceitful conscription of the language of the "democracy," "peace," "inalienable rights," "academic freedom," and American icons like "Abraham Lincoln" by communist front groups to deceive citizens about their actual, clandestine agenda.

\section{II.}

Through the middle of 1938, Dewey and Boas mutually sponsored a variety of liberal-left political initiatives. Both supported United States recognition of the Soviet Union. Boas joined Mrs. Corliss Lamont's Independent Committee for the Recognition of the Soviet Union. ${ }^{25}$ Dewey sponsored and Boas chaired the American Committee on Anti-Nazi Literature. ${ }^{26}$ In addition to allying on several Columbia University campus controversies, they both assisted refugee scholars. Yet, the Spanish Civil War rallied virtually all liberals under the same banner. Dewey and Boas were prominent members of Columbia University Faculty for Aid to the Spanish People. Dewey signed onto an appeal by Boas' University Federation for Democracy and Intellectual Freedom to end the American arms embargo. This 
manifesto condemned also Franco's destruction of academic freedom while the loyalist forces were allegedly providing academic seminars for the troops on the front-line. ${ }^{27}$ Boas tried to solicit Dewey to submit a letter to the New York Times on anti-Semitism in Spain insisting that the letter would be obtain a more favorable audience from someone who was non-Jewish. ${ }^{28}$ While Dewey eventually disengaged from the Spanish Popular Front, Boas redoubled his commitment-even after loyalist forces were defeated. Boas dismissed evidence of Soviet intrigues in Spain. Dewey became aware by stories in The New Leader, from John Dos Passos and Emma Goldman (among others) that Stalin's intrigues in Spain mirrored the Communist Party subversion of democratic liberalism in the United States. At the same time, the Daily Worker lionized Boas in an article, "Papa Boas-Great Scientist Who Mobilizes Culture for Political Liberty." ${ }^{29}$

In 1936, Boas announced his retirement from Columbia University in order to devote his attention full-time to a political campaign against "racism" and "fascism." ${ }^{\prime 30}$ His faculty office was transformed into the epicenter for communist front operations within the scientific-academic world. Boas released a petition signed by 1,284 scientists that repudiated "Nazi" science. ${ }^{31}$ The petition warned, "the agents of fascism in this country are becoming more and more active, and we must join with all men of good will in defending democracy today if we are to avoid the fate of our colleagues in Germany, Austria and Italy." ${ }^{\prime 2}$ Capitalizing on this success, Boas founded the American Committee for Democracy and Intellectual Freedom. During February of 1939, the 1,100 scientists who participated nationally in the ACDIF sponsored Lincoln Day Birthday for Democracy. Then, Boas' New York branch secured the signatures of 2,391educators who condemned the Fascist threat to democracy. ${ }^{33}$ These campaigns were an impressive organizational achievement. Discretely adhering to Popular Front protocol, any reference to Stalin's policy on academic freedom and democracy was omitted.

Collegiality between Dewey and Boas was further aggravated when Boas decided to enlist in the New York Teachers Union. ${ }^{34}$ Four years earlier, Dewey had resigned from the union due to its co-option as a front organization by communist operatives. In a not-so-subtle slight to Dewey, Boas charged that "nothing seems to be more futile than to complain of destructive action of a minority and to answer by withdrawal. The Democrats did not resign their position in Congress because the Republicans bore from within." ${ }^{35}$ Boas further elaborated upon his decision: "my own activities have been up to this time in other lines but the increasing unwillingness within the teaching profession to adhere to the fundamental democratic discussion decided for me to join the Union." ${ }^{36}$ Though probably unnecessary, Boas directed the Union to afford his decision to join maximum publicity. A major if not the major priority of the ACDIF's subsequent agenda consisted of feverishly resisting efforts to oust the teachers union from its affiliation with the American Federation of Teachers. 
Amidst this political-professional cauldron, Sidney Hook and John Dewey co-founded the Committee for Cultural Freedom. Initially, it was titled the Committee Against Totalitarianism but was revised to project a more positive profile. ${ }^{37}$ The title also corresponded with Dewey's new book, Freedom and Culture, that indicted both Nazi and Marxist-Leninist brands of totalitarianism. Dewey's reputation as America's leading liberal spokesman posed an ominous threat to the ACDIF who feared that their organization would assume a "red tinge." ${ }^{38}$ Sidney Hook sent a copy of the Committee for Cultural Freedom's declaration of principles to Boas, inviting him to join. Boas immediately sensed the peril of a "seemingly identical" academic group being established. His suspicions were exacerbated when Hook requested that he send his response to Frank Trager, an officer with the American Jewish Committee..$^{39}$ Divisions deepened when Boas accepted the nomination for vice-president of the Columbia University chapter of the teachers union. ${ }^{40}$ Later that month, George Hartmann, a CCF member and Columbia University faculty member, ran as a vice-presidential candidate with a slate intended to remove Communist control of the entire teachers union. He was defeated. ${ }^{41}$

Boas' remark about the two organizations sharing a common objective opened the possibility of a merger. Both camps engaged in subterfuge. On the day that the CCF's declaration was released to the New York Times, Dewey wrote a letter to Boas reassuring him that the CCF was not directed against him and reaffirming Dewey's "great admiration and for your [Boas'] activities." ${ }^{\text {"42 }}$ Dangling the prospect of a rapprochement, Dewey arranged a meeting with Boas, Hook, and himself on May 25, 1939. ${ }^{43}$ In a flurry of correspondence, Boas berated Hook and Frank Trager for their alleged unwillingness "to cooperate if some opinions differ." Hook wrote to Boas noting that there was "substantial agreement" on many points but that Boas had indicated that a merger wasn't really feasible. ${ }^{44}$ Hook requested that Boas send him a statement of the ACDIF's governing principles. Regardless, merger options were still circulated with Boas proposing a division of labor with the ACDIF tasked with the academic-scientific world and the CCF confined to the literary-cultural domain. Boas was enraged by a story in the New York Times in which Sidney Hook had referred to him as a "fellow traveler." Dewey claimed that Hook was not responsible for the errors in the story and noted that Hook personally sent a letter to the Times in order to correct the distortions. The Times reporter was blamed, allegedly motivated by the desire for a provocative storyline. The New York Times article included a specific sub-title-"Not Aimed at Boas," but Boas was upset because reference was made to some members of the American Committee for Democracy and Intellectual Freedom who maintained a "one-sided" policy of excluding Stalinist repression. No allusion in the article characterized Boas as a "fellow traveler." Boas sent a letter to the New York Times, insisting disingenuously that his group was only concerned with domestic repression. He concluded, "Any group that would actually attack our intellectual freedom would 
be uncompromisingly opposed." Clearly, this did not include the Communist Party. Sidney Hook's letter in the same edition reiterated his opposition to all forms of totalitarianism. Dewey and Hook's strategy seemed designed to separate overtly pro-Stalinist ACDIF members from those who were not. ${ }^{45}$ Endeavoring to distance the person from his politics, Dewey contended that Boas seemed to be unaware of "the use actually made of his organization and his name."46 Years later, Hook acknowledged that Boas not a political neophyte at all. Boas knew exactly what he was doing. ${ }^{47}$ In his correspondence to Boas, Dewey never directly raised the Communist issue though virtually everyone recognized that the CCF inclusion of the Soviet Union as a totalitarian state capsulized the controversy.

The Popular Front press launched a campaign to discredit the CCF. The New Republic refused to publish the document despite the notoriety of those who signed it. Insulted by the innuendos, Dewey, as CCF chairman, sent in a rejoinder ${ }^{48}$ Corliss Lamont rallied the totalitarian left through an open letter signature campaign addressed to "All Active Supporters of Democracy and Peace." Not only did the 400 signers of the letter malign the CCF as "fascist," it ridiculed the "fantastic falsehood that the USSR and totalitarian states are basically alike." ${ }^{\text {"49 }}$ Like the Trotsky Inquiry, CCF members were harassed and intimidated in order to pressure them to resign..$^{50}$ Boas was solicited by Lamont's group to sign the letter. He was confronted with a precarious predicament. ${ }^{51}$ If he did sign the document, as did several ACDIF members, it would furnish compelling evidence that the ACDIF was indeed a Communist front group. Refusing to sign might alienate his political allies. In a confidential letter, Boas nuanced the dilemma by agreeing that the Soviet ideal was "peace, human equality, and education" as opposed to the Nazi glorification of "war and human bondage." He explained that: "In order to succeed rapidly free expression of opinion is ruthlessly suppressed. So far as I am able to judge democratic principles may prevail within the Communist party in Russia, but the benefits of the Constitution are confined to that party." ${ }^{2}$ Though Stalin's goals were different, his means were similar to the Nazis. Boas did not explain how one could collaborate with the Communist Party in dozens of front groups if its methods were treacherous and deceitful. Though he acknowledged (always privately) that academic freedom was circumscribed in the Soviet Union, how could he contend that democratic principles prevailed in the Communist Party in the aftermath of the Purge Trials? Perhaps, he was attempting to placate Corliss Lamont who applauded Stalin's ruthless machinations.

After the Nazi-Soviet Pact, even the Nation admitted that Lamont's manifesto constituted an "unqualified endorsement" of the Soviet system..$^{53}$ Boas' worst fears were realized when the ACDIF was defunded by the American Jewish Committee. ${ }^{54}$ The ACDIF was subsidized with a very substantial grant of $\$ 14,720$ in 1939. If Hook had laid a trap for Boas, Boas became ensnared despite his wariness. Conceding that the Soviet Union was a totalitarian state probably would have sufficed to retain 


\section{Gary B. BULLERT}

funding. Boas blamed Frank Trager and Sidney Hook, insisting that "ever since the beginning Sidney Hook, Trager and others have been trying to discredit us." ${ }^{55}$ Furthermore, he savaged The New Leader. which had become the publicity organ for the CCF, charging that the journal demanded absolute conformity of opinion. They were "red baiters" branding those who differed from them as Communists. ${ }^{56}$ In a letter to Wesley Mitchell, an economics professor at Columbia University, Boas complained that: "It seems it is their opinion [Committee for Cultural Freedom] that the only way to prove you are not a Communist is to attack Russia." ${ }^{57}$ To say the least, Boas didn't deem doctrinal conformity within the Communist Party to be an obstacle to cooperation.

In the aftermath of the Stalinazi Pact, the CCF discerned that the political atmosphere had become more propitious for a merger with the ACDIF. Upon Dewey's recommendation, Boas' original proposal was submitted to the CCF membership for a vote. ${ }^{58}$ Moses Finkelstein, executive secretary of the ACDIF, insisted that it was Dewey, not Boas or Hook, who blocked the merger. ${ }^{59}$ Finkelstein claimed to have a copy of Dewey's letter on file but never provided it. The proposal at the October 1939 CCF meeting was rejected due to the fundamental conflict of only one organization being "committed to opposition of all forms of totalitarianism." 60 On December 9, 1939, the ACDIF's executive committee unanimously rejected the merger. ${ }^{61}$ This decision was indicative of the new Communist Party policy of abandoning the Popular Front strategy. ${ }^{62}$

Trusting in the persuasive power of historical facts, Dewey proposed that a letter be forwarded to all non-Communist Party signers of the Lamont letter inviting them to join the CCF as genuine supporters of cultural freedom and democracy. ${ }^{63}$ A similar letter was sent to the members of the League of American Writers. At the league's Third Congress on June 2, 1939, the platform proclaimed a new goal: "Cooperation of this country with other nations and peoples opposed to fascismincluding the Soviet Union, which has been the most consistent defender of peace." ${ }^{64}$ Only a handful of mea culpas were recorded. Despite the discouraging results, Dewey became temporarily convinced that the Popular Front had self-destructed. On October 13 1939, the CCF sponsored a town meeting, "Cultural Freedom and the World Crisis," featuring W.G. Krivitsky (high ranking Soviet defector) and Harry Gideonse (President of Brooklyn College). A birthday card from Boas to Dewey on his 80th prompted a warming of their personal relationship. Reminiscing over their thirty year career as faculty colleagues, Dewey's letter in response depicted Boas as "a constant and valiant defender of the faith." ${ }^{55}$ This exchange was followed by a Boas letter complaining about a scurrilous cabal to create a political rift between them. ${ }^{66}$ Boas reaffirmed his commitment to "true democracy" entailing "absolute intellectual and spiritual freedom." Boas conducted a campaign to suppress the academic freedom of any group or organization he suspected to be racist or proNazi. He also espoused the current isolationist party line on foreign policy. Boas 
made no reference to the Soviet Union. Dewey replied that no one had approached him about his differences with Boas and he promised to investigate the source of these rumors. ${ }^{67}$ Could Dewey have possibly deemed Boas' ubiquitous Communist front activities as a means to "true democracy"?

At the same time, Dewey wrote to Hook and Trager, apparently resigning as Honorary Chairman of the Committee for Cultural Freedom. With the Popular Front discredited and the CCF "successfully launched," Dewey surmised that "the crisis that required his chairmanship no longer existed." ${ }^{68}$ The Popular Front may have been wounded temporarily but Stalinism did not implode. Did a rift develop between Dewey and Hook? Dewey maintained that fellow travelers and liberal dupes were a greater threat than actual party members. ${ }^{69}$ Instead of undermining Dewey, Hook defended him and proceeded to engage publicly fellow travelers, including Corliss Lamont, Freda Kirchwey, Upton Sinclair, George Soule and Frederick Schuman. Hook reminded the CCF that "Crypto-Stalinism has been the curse of American culture for the last few years. ... It is already retreating from its mild criticism of the Stalinazi Pact." ${ }^{\prime 0}$ According to Kutulas, Dewey simply wanted to have the CCF defend civil liberties without the baggage of the ACLU, which defended civil liberties at home while acquiescing in Stalin's total abuse of them abroad. In fact, both Dewey and Hook withdrew support from the ACLU because Harry F. Ward, an ACLU executive committee member, signed Lamont's "letter of 400." Hook charged that Ward had worked "constantly with the Communist Party in this country to vilify critics of Russian terror." ${ }^{71}$ Hook prioritized a civil liberties agenda for the CCF. ${ }^{72}$ After the Stalinazi Pact, Roger Baldwin repudiated the Popular Front and cooperated with the CCF. ${ }^{73}$ Franz Boas signed an open letter urging the ACLU to reverse its ban on officers who were Communist Party members. ${ }^{74}$ Later, Baldwin attempted unsuccessfully to remove Boas from the New Jersey ACLU state committee. ${ }^{75}$

Dewey may not have been fully cognizant of how Boas' Soviet activism dramatically intensified after the Nazi-Soviet Pact. Boas rejected an invitation to join a group headed by Ephrain Schwartzman that strove to promote anti-Fascism without a Stalinist affiliation. Boas replied that his focus was riveted on domestic politics and he wouldn't direct his time and attention to foreign affairs. ${ }^{76}$ Less than a month later, Boas promoted an ACDIF anti-war resolution that mirrored the Communist party line. ${ }^{77}$ Any reference to anti-fascism was tactfully avoided. When a vote was conducted of the executive committee, it passed by a six to two margin. However, when submitted to the national committee it won narrowly and the resolution was dropped. Another Boas-sponsored organization, the American Association of Scientific Workers, adopted a virtually identical statement. ${ }^{78}$ Contrary to his bellicose stance in the Spanish Civil War, Boas now declared, "war raises emotions to a frenzy. War obscures the clarity of vision of the people, engulfs the scientist himself in the passions of the day. ... It has no place in democracy that 


\section{Gary B. Bullert}

gives freedom to all." 79 Boas enlisted in Bella Dodd's Committee to Defend America by Keeping Out of War, the New York Conference for Inalienable Rights, and the National Emergency Committee for Democratic Rights. As a member of the Executive Board of the American Council Against Nazi Propaganda, Boas agreed to dissolve the organization as a fraternal gesture to Stalin's new ally. ${ }^{80}$

\section{III.}

By the beginning of 1940, the cold war between the CCF and ACDIF metastasized when Dewey signed a petition calling for the discontinuance of the American Committee for Democracy and Intellectual Freedom on January 17 th. ${ }^{81}$ Boas wrote to the American Jewish Committee, indicating that Dewey also wanted the Dies Committee abolished. Dewey did sign a CCF petition advocating that Dies be removed as chair of the committee, not that the committee be abolished. Dewey implored Boas to retract this misrepresentation in writing to the American Jewish Committee. ${ }^{82}$ Boas did not comply with this request. Instead, he resorted to appealing to their long-standing personal relationship and reiterated that "fundamentally we take the same position." ${ }^{83}$ In a strongly-worded reply, Dewey dismissed Boas' allegations of outside parties poisoning their relationship as "totally false" and that Boas also put Frank Trager in a "false light." ${ }^{4}$ At the same time, Dewey resumed actively his honorary chairmanship of the Committee for Cultural Freedom. On February 12, 1940, he participated on a CCF committee regarding membership dues and was named as the author of a "foreword" in a upcoming CCF book on Cultural Freedom. ${ }^{85}$ In a letter to the New York Times, Dewey (identifying himself as a CCF member), defended the legitimate right of the government to investigate education. ${ }^{86}$ While cautioning against a committee being subverted for partisan political purposes, he did not implicate the Rapp-Coudert committee investigation of the New York Teachers Union. Indeed, this committee had not begun to conduct hearings. The American Federation of Teachers adopted a resolution endorsing Dewey's position: criticizing the Dies Committee but not its right to exist. ${ }^{87}$ The Rapp-Coudert investigations emerged as a major battleground between the ACDIF and members of the Committee for Cultural Freedom.

In April 1940, the CCF published its report on "Stalinist Outposts in the United States." It was crafted to supplant the non-scholarly research of the Dies Committee that failed to identify many Communist front groups and misrepresented others. Among the Boas-sponsored groups listed were the National Emergency Conference, the Council for Pan-American Democracy, and the University Federation for Democracy and Intellectual Freedom. ${ }^{88}$ Curiously, the New York Teachers Union was not listed in the report nor was the American Committee for Democracy and Intellectual Freedom, or the American Association of Scientific Workers. Boas was never mentioned. Eugene Lyons, a CCF member, famous for naming names, excluded Boas entirely in The Red Decade. Boas joined Bella Dodd's 
Committee for the Defense of Public Education. Charles Hendley, Teachers Union Local 5 president, signed Lamont's letter of 400 and later formally joined the Communist Party. His executive secretary, Dorothy Williams, was identified by Bella Dodd as a Communist Party member as well as her brother, Dale Zysman, who was vice-president of the Union. Bella Dodd, the Union's legal-legislative counsel, operated under the direction of the Communist Party. Despite her desire to become a card-carrying member, party officials determined that she would be more effective as a non-member. She later became a member of the National Executive Committee of the CPUSA. ${ }^{89}$ She testified before a Senate Sub-committee and revealed that two-thirds of the union's Executive Board and twenty-five percent of the faculty at Brooklyn College and the City College of New York were party members. Historian Clarence Taylor conceded that her testimony, similar to Whittaker Chambers'

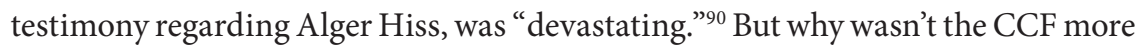
combative when it came to the teachers union?

During the honeymoon period of the Nazi-Soviet Pact, the American Committee for Democracy and Intellectual Freedom devoted itself to issues of academic freedom, peace, and "civil rights" for Communist Party members. For example, Boas sponsored Dashiell Hammett's "Bill of Rights Declaration" in conjunction with the trial of Earl Browder. ${ }^{91}$ Annoyed at allegations of Communist infiltration of many front groups, including the ACDIF, Boas stated that it was irrelevant if these groups included Party members so long as they shared a common cause. Their political commitments were "none of his business." 92 When questioned about the sincerity of Communist Party members' avowals of peace, he reasoned if they embraced "peace currently" it should be no impediment to cooperation. Joining Communist-dominated organizations also posed no problem since he could provide a "pluralistic influence." Besides, he insisted that "the ultimate aim of Communism does not conflict with liberty and the greatest happiness for everybody." ${ }^{\prime 3}$ Specific political initiatives included opposition to the deportation of Harry Bridges (head of the Longshoreman's Union and Communist Party member) and lobbying for the parole of Communist Party chief, Earl Browder. Historian Carl Becker repudiated this initiative by asking Boas why a democratic society should tolerate a subversive who exploited democratic freedoms in order to destroy them. ${ }^{94}$

\section{IV.}

The Committee for Cultural Freedom ceased regular operations during the middle of 1940. One subsequent reference (May 5, 1941) to the CCF involved Mrs. Isabel Lundberg, executive secretary, repudiating a charge by the teachers union in league with the ACDIF that her organization didn't provide support for Bertrand Russell when he was denied an appointment at CCNY.95 Dewey and Hook, among others, vigilantly defended Russell, even publishing a book on the case. ${ }^{96}$ Russell became a member of the CCF and not the ACDIF. The Rapp-Coudert investigations elicited 
the cooperation and testimony of several CCF members. Speaking on behalf of the ACDIF, Boas castigated the hearings as "a tyrannical attempt to take from teachers and pupils the right to hold whatever religious and political opinions they wish." ${ }^{97}$ On November 15, 1940, Harry Gideonse, CCF member and president of Brooklyn College, gained overwhelming support from the faculty senate (42-7) to fully cooperate with the investigation. ${ }^{98}$ President Harry Wright of the City College of New York received a similar endorsement by faculty on that campus. He asserted that "it was impossible for a disciplined Party member to function as a responsible teacher." A New York Times article declared: "the Faculty Council of the College of Liberal Arts announced last night that it had adopted a resolution in 'complete agreement and thorough approval' of Dr. Wright's support for the RappCoudert Committee. ${ }^{\prime 99}$ A Communist Party directive admonished teachers that: "Marxist-Leninist analysis must be injected into every class.... Communist teachers must take advantage of their positions, without exposing themselves, to give their students to the best of their ability working-class [i.e. Communist] education." 100 The elections conducted by the Communist-controlled teachers union provided a playbook for subsequent "peoples' republics". In 1937, Charles Hendley obtained 3,333 votes and his three opponents one each. The union adopted a policy of not allowing the rank-in-file membership to publicly criticize the party. School libraries even engaged in banning any books mildly critical of the Soviet Union, according to Henry Linville, head of the Teachers' Guild. ${ }^{101}$

Dr. Bernard Grebanier (CCF member, ex-party member, and professor at Brooklyn College) testified before the Rapp-Coudert Committee, identifying over thirty Communist Party faculty ${ }^{102}$ Members of the Anti-Stalinist Left, like Jay Lovestone and Harry Gideonse, proved to be expert witnesses. Sidney Hook also testified before the Committee:

In any college where you have a group of people organized in a conspiratorial manner, who take their instructions from a foreign power-because the basic value and allegiance of the Communist power is oriented toward Russia, and that can be documented in a thousand details where you have such a group who publishes newspapers, organizes the students, aims to inculcate a point of view which is laid down by a foreign power, and then the very pre-supposition of educational freedoms are undermined.... So that I think there can be no question but that if a conspiratorial group of that sort existed on the campus, it would make impossible the work of education of the university or college as such. ${ }^{103}$

Yet Hook opposed federal and state investigations of academic institutions even though he acknowledged the conspicuous ineptitude of academics to police themselves. ${ }^{104}$ Ferdinand Lundberg, CCF secretary, concluded that the Rapp-Coudert Committee "has been conducted as a model in judicial decorum for precise fact." 105 On December 29, 1940, the American Federation of Teachers conducted their own 
independent investigation of the New York Teachers Union. Their findings dovetailed with those of the Rapp-Coudert Committee, concluding that "as long as the Communist Party is a significant force in the American Federation of Teachers we can be united only under their program. It is, therefore, necessary to eliminate this influence." 106

Would circumstances ever exist to warrant a legislative investigation? How responsibly did the Rapp-Coudert Committee conduct its investigation? In contrast to the Dies Committee, historian M. J. Heale concluded that: “The Rapp-Coudert committee went about the process of exposure carefully, and its hearings became a model for later congressional probes." ${ }^{\prime 107}$ The committee utilized only direct sworn testimony from competent witnesses, mostly ex-Party members, and then this testimony had to be corroborated by additional witnesses. This threshold provided amnesty for several Brooklyn College faculty who were indicted by just one witness. In the teeth of a savage character assassination mounted by Communists, William Canning identified fifty-four Party members among the City College faculty. Specific documentation of organizational meetings and publications reinforced the testimony. ${ }^{108}$ The sophistication and propriety of the committee's attorneys (Paul Windels, Philip Haberman, and Robert Morris) disarmed the Party apologists. ${ }^{109}$ The Rapp-Coudert Investigation vindicated and reinforced the case that Dewey and Hook advanced for years. What would have transpired in the absence of the investigation? In light of the magnitude of Communist subversion in the teachers union, the Rapp-Coudert Committee was arguably warranted as the only viable option.

Both Senator Coudert and Harry Gideonse exchanged vituperative correspondence with Boas and the ACDIF. ${ }^{110}$ The ACDIF actually mobilized against the Coudert investigation on April 18, 1940, well before the committee convened. Its protracted campaign included distributing 10,000 copies of the Executive Committee's vilification of the investigation(December 18, 1940), inducing 200 clergy and 774 college administrators to endorse their Statement of Principles on the Rights of Teachers(April 28, 1941), and submitting a petition to the Board of Higher Education, signed by 250 faculty and clergy) to revoke the teachers' suspensions. This activity provides testimony to the magnitude of the pro-Stalinist network. Moses Finkelstein, ACDIF executive secretary, was himself a defendant in the Rapp-Coudert investigation. He was exposed as a Communist Party member under corroborated testimony and later named by Bella Dodd as a member. Dodd strategized with Boas and Finkelstein regarding both the Union decertification and the Rapp-Coudert investigation. In a letter to Charles Hendley, Boas lauded Finkelstein: "The effectiveness of the Committee [ACDIF] is almost entirely due to the work of M. I. Finkelstein whose devotion and ability deserve the highest praise."111 Finkelstein was unanimously reappointed as executive secretary. J. Robert Oppenheimer was an active member of the ACDIF and American Association of Scientific Workers. he dispatched a venomous letter to Senator Coudert. ${ }^{112}$ In 1942, 
the House Un-American Activities Committee listed the ACDIF as a communist front group and this damaging evidence surfaced during Oppenheimer's national security clearance hearings. In a letter to Brooklyn College faculty, President Gideonse condemned the smear tactics of the ACDIF while endorsing the Coudert Committee for upholding the "most ordinary standards of human conduct." ${ }^{113} \mathrm{He}$ challenged Boas to supply any statement of the ACDIF, not to mention the Teachers Union, critical of Stalin. Under the shibboleth of "teachers' rights," he charged that the Union politicized the schools, committed perjury, concealed their identity by using Party aliases and refused to provide their membership list. On Finkelstein's recommendation, Boas attempted to cultivate a "sympathetic" liberal member of the New York Board of Education, I.M. Hirschman. Boas was rebuffed when Hirschman indicated that he was convinced that Finkelstein was a Communist and voted in favor of firing him. ${ }^{114}$ Notably, Ordway Tead, liberal chairman of the Board of Education, who was a speaker at the ACDIF's Lincoln Day Birthday for Democracy(February, 1939) renounced his initial sympathy for the Teachers Union and strongly supported the Coudert committee.

Submitting to Party discipline, teacher witnesses denied under oath that they were Communist Party members. Confronted with overwhelming evidence, Morris Schappes, an executive board member of the College Teachers Union, finally admitted that he was a Party member. He was convicted of perjury. One of his students at CCNY was Julius Rosenberg. Schappes later acknowledged that lying under oath in defense of Stalinist cause was a transcendent calling. He implemented Lenin's injunction that: "To speak the truth is a petite-bourgeois habit. To lie, on the contrary, is often justified by the lies' aim." ${ }^{115}$ Defending Schappes to the end, Boas joined the Schappes Defense Committee and the ACDIF claimed that "reasonable doubt" absolved Schappes from guilt. ${ }^{116} \mathrm{He}$ was the only Communist Party member to serve prison time - fourteen months. Only fifty Communists were removed as teachers, a miniscule percentage of the actual Party members. The Rapp-Coudert Committee possessed no power to indict anyone. In 1940, the New York Board of Education agreed to cooperate with the investigation. Its policy statement resolved: "that it is the intention of the Board to adhere to its established policy and not discharge any members of its staffs 1) merely because of membership in a political organization or 2) merely because of any differences of opinion on political, economic, or social matters." 117 Like the Rapp-Coudert Committee's preference, the Board reiterated that the public schools and universities ought to be the vehicles for upholding the integrity of the academic process and conduct their own investigations. This formulation anticipated many of Sidney Hook's distinctions in his subsequent book, Heresy, Yes - Conspiracy, No.

The accused teachers attacked the Rapp-Coudert Committee not only with "red baiting" accusations; they implicated it in a vast conspiracy to draw the United States into an "Imperialist War." Sidney Hook recalled that he saw Boas sporting 
a "Roosevelt Is a Warmonger" button around the campus. ${ }^{118}$ After the Nazi attack on the Soviet Union, the ACDIF promptly adjusted its dialectical bearings by vacating its pacifist-isolationist position in favor of stoking the war factories in order to provide "upmost material assistance" to the Soviet Union. The ACDIF announced that "science and the arts, literature, and education have been either wiped out entirely or twisted to barbaric and inhuman ends wherever fascism has laid its hands." ${ }^{119}$ Soviet participation in the war compelled them to speak more resolutely because anti-Stalinism functioned as a surrogate for abetting Nazism. By October 1, 1941, the ACDIF was circulating a petition demanding full belligerency or total war for the United States. Boas' American Peace Mobilization, which was picketing the White House the day before Hitler's invasion, abruptly changed it name to the American Peoples' Mobilization. ${ }^{120}$ President Gideonse anointed Boas with the title of a "June 22 patriot." 21 Boas forwarded a membership invitation, noting their "common attitude," to ex-Soviet ambassador, Joseph Davies, after the release of his book, Mission to Moscow. ${ }^{122}$ The book adamantly defended the Moscow Show Trials and claimed that Trotsky was a Nazi agent. Both John Dewey and Sidney Hook condemned the book as transparent Stalinist propaganda. ${ }^{123}$ When the book resurfaced as a Warner Brothers movie, Corliss Lamont led a New York rally, honoring the producers and labeling critics of film as "unpatriotic."124 With regard to patriotism, Soviet Archives disclosed that Lamont had indicated his willingness to perform espionage work for the Kremlin. ${ }^{125}$ With the new Popular Front sanctioned by the Roosevelt Administration, the foreign policy repercussions were ominous. On February 2, 1942, Dewey wrote to George Lundberg, "I am afraid when we come make peace, a high price will be paid the present coddling of the Stalinist regime." 126 Dewey and Hook were early advocates of a resolute policy of containment.

\section{V.}

After the American Federation of Teachers elected George Counts as President, Franz Boas, Moses Finkelstein, and Bella Dodd prepared a strategy for the 1941 national convention hoping to capitalize upon Hitler's attack. Depicting the European conflict as a war between democracy and totalitarianism, Boas addressed the convention by condemning the expulsion of the New York Teachers Union as "a disastrous adoption of totalitarian methods." ${ }^{27}$ Congratulating Counts on his victory over the Communists, Dewey also sent a message to the Convention: "If I were present in person, I should want to pay especial regards to old friends with whom I was associated in the past and who never yielded the least ground in their battles for teachers, for the labor movement in association with teachers and for the freedom of unionism from subjection to foreign political influences." ${ }^{28}$ Yet, the defeat of the Communists was largely mitigated by the advent of the war. Anticommunists were now on the defensive. 
The avalanche of evidence compiled by the Rapp-Coudert Committee impressed a critical consensus of observers including the New York Times, despite its education editor, Benjamin Fine, being a Communist Party member. The RappCoudert Committee temporarily prevailed in the public relations battle. The newspaper editorially endorsed the Committee by concluding that, "these methods [CPUSA's] are not methods of a legal and open political party, seeking to gain control of government only through the ballot box. They are the methods of a conspiracy." ${ }^{129}$ Republicans and Democrats are not funded and controlled by Moscow and do not destroy their records. Endorsing the renewal of funding for the Coudert Committee, the editors declared: "Senator Coudert and his counsel, Mr. Paul Windels uncovered some shocking facts. There is no doubt whatever that members and friends of the Communist Party deliberately misused their teaching positions for that party's purposes." 130 This judgment was confirmed by the release of an official Communist Party document revealing that there were "many hundreds" of Party members in the Union. According to Party officials, they had enlisted many more than necessary in order to achieve their political objectives. George Counts utilized this evidence at the American Federation of Teachers convention to substantiate his case. In her subsequent testimony, Bella Dodd placed the number of Communist Party members at 1,500. ${ }^{131}$ At the same time, Irving Kristol, a member of Hook's American Committee for Cultural Freedom, published a provocative article, "Civil Liberties, 1952 - A Study in Confusion," that chastised the solicitude of many liberals for the Communist Party. In effect, he insisted that they facilitated a right to conspiracy which no sustainable government could permit. ${ }^{132}$

Though Sidney Hook has been excoriated as an "extremist" and the Committee for Cultural Freedom condemned as "virulently anti-Communist," these feverish attacks by the totalitarian Left conceded tacitly that liberal anti-Communists provided a formidable intellectual foundation for anti-Stalinism. ${ }^{133}$ It could no longer be dismissed as reactionary bigotry. If anything, the Dewey-Hook approach might have been too reasonable and conciliatory. With only a handful of recantations after their inquiry to the Lamont group and League of American Writers, the Committee for Cultural Freedom may have overestimated the persuasive power of logic and factual evidence. ${ }^{134}$ Stalinist dogma rendered Party members largely impervious to counter-veiling evidence; fellow travelers' self-corruption pivoted upon the intellectual hubris of concocting facile rationalizations for every emerging event that didn't automatically conform to their ideology. Undoubtedly, Franz Boas was the leading fellow traveler among American scientific-academic circles. ${ }^{135}$ At the time, neither Dewey nor Hook would publicly acknowledge this fact. Indeed, they both recognized that fellow travelers were a graver menace than card-carrying Communists. However, there were far too few Sidney Hooks. He argued that the most effective technique for awakening fellow travelers consisted of showing them actual Soviet documents, including the entire front strategy, and those requiring 
absolute subservience by American Party members to Moscow. How many were converted and how many political epiphanies resulted from the most recent disclosure of Soviet archival material? By exposing how the Party was funded and micro-managed by Moscow, identifying the duplicitous charade of various front groups, and articulating the genuine principles of democracy, the CCF endeavored to convince fellow travelers and potential fellow travelers of their political myopia. Judy Kutulas depicted Hook as an embittered fanatic on a vendetta to ridicule and humiliate his opponents while Dewey was accommodating and magnanimous. Hook allegedly made "outrageous demands on progressives, alienating them and provoking responses by the CPUSA." ${ }^{\prime 36}$ Hook provoked them to engage in a vicious smear campaign? She never delineated of what these outrageous demands entailed. Ostensibly, after the Stalinazi Pact, Dewey and Hook wanted the Lamont group and the League of American Writers to retract their smear of Dewey and the CCF as being "fascist." Was this a humiliation or an act of common decency? Probably, the worst offender of all, Corliss Lamont did try to salve some wounds by writing a letter to Dewey denying that he thought that Dewey personally was a "fascist." Dewey responded by reminding Lamont of the concerted pestering by late phone calls, bullying and harassment of many other members of the Committee for Cultural Freedom that was crafted to stampede resignations.137

When the second romance of Stalinism blossomed further after World War II, the American Committee for Cultural Freedom was established. Hook delineated the "psychology of the fellow traveler," but he still refrained from mentioning Franz Boas. Hook did cite the very successful manifestos circulated by the American Committee for Democracy and Intellectual Freedom and identified it as a "Communist front organization." ${ }^{138}$ Hook's fellow traveler typology matched Boas' political DNA: 1)members or sponsors of over twenty front groups(Boas' list was well over forty), 2) possessed high intelligence within their own specialized field, 3) and a big name to lure recruits often with a party planted executive secretary(Moses Finkelstein). Their ubiquitous tenets included: 1) the Soviet Union is a progressive society whose transitory flaws(revolution in a hurry) would dissipate over time, 2) the Soviet Union's humanitarian ends should be definitive, not its sometimes troubling means, 3) one should work with Communists for any progressive cause or organization(not disavow them), 4) when confronted with facts surfacing about Stalin's misdeeds, these should be ignored, have judgment suspended or claim that the internal affairs of the Soviet Union are none of our business, and 5) defame critics as either reactionary bigots or dupes who were operationally abetting fascism(which side are you on motif). Hook cautioned that domestically "anyone who works with the Communists works for them.".139

When Frank Bohn resigned along with Julius Lips as Honorary Presidents of the German-American League for Culture due it being co-opted by Communists, Boas pleaded: "I am certainly for liberty, democracy and peace, just like you. But, 


\section{Gary B. Bullert}

so far, I had to avoid certain issues and I had to do that in the in the interest of the maintenance of the anti-fascist front." ${ }^{\prime \prime 40}$ Boas denied to the bitter end that Moses Finkelstein was a Communist while insisting that it wouldn't make any difference if he was. Is the refusal to tell the truth about Stalin (Boas privately admitted it), on the same level of dishonesty as lying before a legislative committee? The FBI file on Franz Boas referred to him as a "concealed Communist" operating "under Communist discipline" but not a Party member. ${ }^{141}$ However, Hoover erred in depicting him as a gullible stooge. The CCF outreach program to Boas failed because it presumed that Boas was an honest though misguided liberal. Hook's recommended that: "they [fellow travelers] should not be hounded or martyrized but educated." "142 Unfortunately, Boas was intractable. Not until Hook's autobiography did he designate Franz Boas as a "fellow traveler." ${ }^{143}$ Boas was a hybrid "fellow traveler," closer to Corliss Lamont than New Republic editor, Malcolm Cowley.

Were Dewey and other CCF members justified in their campaign to revoke the Teachers Union charter? In a recent book, Clarence Taylor concedes that the Union was dominated by Communists, both in leadership and with over 1,000 rank-in-file party members, allied itself with other Communist front groups, and steadfastly adhered to the party line. Yet, he rebottled the question to consist of whether it is possible for a Communist-dominated Union to better the working conditions of its members? Since the Teachers Union sought to increase salaries, repeal the Ives Loyalty Oath, reduce class size, and promote pension reform, its ousting from the American Federation of Teachers was "undemocratic" regardless of its fidelity to Moscow. ${ }^{144}$ This contention further embellishes the Ellen Schrecker narrative that champions the Communist Party teachers as pedagogical role models who never attempted to proselytize students, were totally objective in the classroom and in their scholarship, only rarely interacted with Communist Party students for political purposes, and didn't deploy their faculty positions to recruit and promote other like-minded individuals. At the outset, she might have consulted the hundreds of pages of testimony compiled by the Rapp-Coudert Committee. Schrecker focused upon their benign motives for joining the Party. They were Stalinists with a human face; knowledge workers - though not exactly egalitarians of the proletarian variety. Her primary source of evidence was reducible to interviews with Communist Party members themselves. ${ }^{145}$ Nowhere did she demonstrate independent thinking by Party members. She revealed that one dissident professor, Marc Grubard, a Columbia University biologist, was expelled from the Party. His crime consisted of "Belittling Party Authority." 146 To her credit, Schrecker was troubled by the Communist Party teachers ritualistically following the party script by lying under oath. A Board member, S.J. Woolf, in the case of labor historian, Philip Foner, remarked: "In recommending the dismissal of Foner, I do not do so because the prosecutor proved him to be a Communist, but because in doing this, he also showed himself to be a liar." ${ }^{\prime 47}$ The willingness of teachers to lie proved to be pivotal. 
In an unending campaign to vindicate the Communist Party teachers, revisionist historians have collaborated in anointing them with victimhood. Political fashion, not evidence from a reopened investigation, resulted in the City University Board of Trustees apologizing "with profound regret at the injustice" done to the dismissed faculty. In June, 1982, Moses Finkelstein was awarded an honorary doctorate from City College. ${ }^{148}$ Though he also lied under oath, Jack Foner characterized the episode as "an honorable experience," adding that the Rapp-Coudert Committee had "really no evidence to support it."149 What would be his judgment on the legal propriety of the Moscow Show Trials? Did any of these defendants object to these proceedings? Franz Boas? He has been memorialized by an annual Franz Boas Award sponsored by the American Anthropological Association.

Scholarship of the American Communist Party has fallen into three categories: 1) the Communist Party was intrinsically subversive and undemocratic, 2) the Communist Party in practice did no real harm, 3) Communist Party members were steadfast soldiers for social justice. The Communist Party Card provided concrete bona fides of revolutionary authenticity. However, card carriers were only one layer of the Communist apparatus in the United States. Along with Harvey Klehr, Sidney Hook was a proponent of category one. Party membership establishes a justifiable suspicion of unfitness to teach. If they place their professional role above party membership, they are simply not practicing Communists.

The Sidney Hook Centennial convened at the Graduate University of New York (December, 2002) fully exhibited the contentious atmosphere surrounding his legacy as the proceeding was dominated by the "Communists as teachers" issue. Arthur Schlesinger Jr. took advantage of the opportunity to exact revenge, charging that Hook "let anti-communism consume his life to the point, like Aaron's rod, it swallowed everything else." He claimed that Joseph McCarthy was a greater threat to American political and intellectual freedom than Joseph Stalin. Christopher Phelps, author of Young Sidney Hook, depicted Hook's abandonment of revolutionary Marxism in favor of Dewey's pragmatic liberalism as a debilitating retrogression. He argued that when Hook abandoned Trotskyism and embraced Deweyan pragmatic liberalism, he acquiesced in status quo liberalism. Tacking in the opposite direction, Robert Westbrook labored to separate Dewey from Hook as a means of transforming Dewey into a radical icon. ${ }^{150}$ Both Dewey and Hook were vigilant enemies of Stalinism in all of its incarnations. In a letter to Bertha Aleck, Dewey observed that: "It's a tragedy that Russia turned out as she has - Stalin is the one of the great Judas Iscariots of history and since he is what he is, it is well to have it made apparent, though of course the good party fanatics won't see it." ${ }^{151}$ The Stalinist Left initially targeted John Dewey for ridicule and ostracism. By the late 1940s, ostracizing Sidney Hook has been a fixation and remains in play today. Hook was Dewey's leading defender both philosophically and politically as Dewey himself recognized. The Committee for Culture Freedom did not inspire McCarthyism but 


\section{Gary B. Bullert}

offered a responsible alternative to its excesses. Rather than being a dress rehearsal for 1950s McCarthyism, the 1930s were a dress rehearsal for the radical 1960s and the political correctness agenda that continues to poison political and academic discourse in this country.

\section{ACKNOWLEDGMENTS}

I appreciate assistance from the Center for Dewey Studies, Tamiment Library, and the Hoover Institute.

\section{BiBLIOGRAPHY}

Brown, Michael, ed. New Studies in the Politics and Culture of U.S. Communism. New York: Monthly Review Press, 1993.

Bullert, Gary. The Politics of John Dewey. Buffalo, NY: Prometheus Books, 1983.

Cotter, Matthew, ed. Sidney Hook Reconsidered. Buffalo, NY: Prometheus Books, 2004.

Dewey, John, and Horace Kallen, eds. The Bertrand Russell Case. New York: Viking Press, 1941.

Diggins, John. The Promise of Pragmatism. Chicago: University of Chicago Press, 1994.

Dodd, Bella. School of Darkness. New York: Kennedy, 1954.

Haynes, John Earl, Harvey Klehr, and Alexander Vassiliev. Spies. New Haven, CT: Yale University Press, 2009.

Heale, M. J. American Anti-Communism: Combating the Enemy Within, 1830-1970. Baltimore, MD: John Hopkins Press, 1990.

Hook, Sidney. Personal Power and Political Freedom. New York: Criterion Books, 1959. -_- Out of Step. New York: Harper \& Row, 1987.

-_- Convictions. Buffalo, NY: Prometheus Books, 1990.

Kengor, Paul. Dupes. Wilmington: ISI Press, 2010.

Kutulas, Judy. The Long War: The Intellectual People's Front and Anti-Stalinism, 1930-1940. Durham, NC: Duke University Press, 1995.

Kuznick, Peter. Beyond the Laboratory: Scientists as Social Activists in 1930s America. Chicago: University of Chicago Press, 1987.

Lyons, Eugene. The Red Decade. New York: Bobbs-Merrill Co., 1941.

Morris, Robert. No Wonder We Are Losing. New York: The Bookmailer, 1955.

Phelps, Christopher. Young Sidney Hook. Ithaca, NY: Cornell University Press, 1997.

Polenberg, Richard. In the Matter of J. Robert Oppenheimer: The Security Clearance Setting. Ithaca, NY: Cornell University Press, 2002.

Powers, Richard Gid. Not Without Honor. New York: The Free Press, 1995.

Taylor, Clarence. Reds at the Blackboard: Communism, Civil Rights, and the New York Teachers Union. New York: Columbia University Press, 2009.

Westbrook, Robert. John Dewey and American Democracy. Ithaca, NY: Cornell University Press, 1991. 


\section{NOTES}

1. Sidney Hook, Out of Step (New York: Harper \& Row, 1987), 271-274. I am grateful for the assistance of the Hoover Institute, Center for Dewey Studies, and Tamiment Library on this project.

2. Ellen Schrecker, No Ivory Tower (New York: Oxford University Press, 1986), 25. For a more recent installment of the controversy, see Ronald Radosh, "A Campus Dress Rehearsal for McCarthyism?" Minding The Campus (August 11, 2011), 1- 4.

3. Peter Kuznick, Beyond the Laboratory: Scientists as Social Activists in 1930s America (Chicago: University of Chicago Press, 1987), 221.

4. Andrew Feffer, "The Presence of Democracy: Deweyan Exceptionalism and Communist Teachers in the 1930s," Journal of the History of Ideas (January, 2005), 93.

5. Stephen Leberstein, "Purging the Reds: The Rapp-Coudert Committee in New York, 1940-1942," in Michael Brown, ed., New Studies in the Politics and Culture of U.S. Communism (New York: Monthly Review Press, 1993), 115; Philip Taft, United They Teach (Los Angeles: Nash Publishing, 1974), 34 - 35.

6. “Teachers Who Quit Union Form Guild," New York Times (2 October 1935), 25.

7. “5,000 Reds Battle With Socialists at Party Rally”, New York Times (17 February 1934), 1.

8. John Dewey to Roger Baldwin (March 29, 1934), Dewey Correspondence (Center for Dewey Studies), Carbondale, Illinois. Hereafter (Dewey Correspondence)

9. Sidney Hook, Out of Step, 500.

10. John Dewey, "Why I Am Not a Communist," Modern Monthly (April, 1934), 137.

11. “The Russian Executions," New Republic (27 February 1935), 77.

12. Horace Kallen to Alfred Hirsch(12/26/1934), Professional Correspondence of Franz Boas, American Philosophical Society, Philadelphia, PA (hereafter PCFBAPS).

13. John Howard Lawson to Nation editor, Oswald Garrison Villard (12/30/1934), PCFBAPS.

14. Franz Boas to Alfred Hirsch (1/15/1935), PCFBAPS.

15. Dewey meets with Novack, Dewey Chronology (Center for Dewey Studies); Hook, Out of Step, 227.

16. Suzanne LaFollette to Leon Trotsky (3/5/1937), Dewey Correspondence.

17. Published in Soviet Russia Today (March, 1937); "Trotsky Inquiry Under Fire Here," New York Times (17 February 1937), 4. See “Is John Dewey Honest?” New Masses (January $4,1938)$. It is noteworthy that two subsequent defendants in the Rapp-Coudert Investigation, John Ackley and Margaret Schlauch, signed the Lamont letter.

18. Sidney Hook, "Corliss Lamont: Friend of the G.P.U.," Modern Monthly (March 10, 1937), 5 - 8. Dewey condemned the deceitful tactics of the Stalinists. John Dewey to E.A. Ross (2/19/1937). Dewey Correspondence.

19. John Dewey to Sidney Hook (3/10/1938). Dewey Correspondence.

20. George Novack to Leon Trotsky (2/15/1937). Dewey Correspondence. On the Dewey - Lamont exchange, see Dr. Dewey Warns on Soviet Tactics, New York Times (7 March 1938), 10; Dewey Chronology, Center for Dewey Studies, Carbondale, Illinois.

21. "New Soviet Trial Called 'Frame-up,' New York Times (2 March 1938), 14; Dewey Group Urges Troyanovsky to Disprove Soviet Trial Story," New York Times (7 March 1938), 4.

22. "No Soviet Statement by Boas," New York Times (5 March 1938), 4. In a subsequent episode, Paul Blanshard, supported by John Dewey and Sidney Hook, tried to prevent the takeover of the American Labor Party by Communists. He chararcterized the battle as one 
between democracy and a totalitarian cabal orchestrated from Moscow. Boas was listed on the letterhead of Blanshard's group. Morris Watson, head of the Progressive Committee to Rebuild the American Labor Party, contacted Boas and instructed him to remove his name from the letterhead. Four days later, Boas wrote Blanshard that his name not be used because he opposed any group that excluded Communists. He proclaimed, "I am opposed to any movement that is liable to lead to the investigation of slightly different approaches to the problems of the Party." When Watson exploited the incident by claiming publicly that Boas' name was used illicitly, Blanshard contacted Boas, informing him that he had a copy of Boas' membership letter in his possession. Two months later, Boas wrote a disclaimer to the New York Times. The Communists did succeed in capturing the American Labor Party. Morris Watson to Franz Boas(2/22/1940), PCFAPS; Franz Boas to Paul Blanshard (2/26/1940), PCFBAPS; Paul Blanshard to Franz Boas(3/11/1940), PCFBAPS; “Boas Explains Stand," New York Times (16 May 1940), 6.

23. John Dewey to Corliss Lamont (3/6/1938), Dewey Correspondence; George Novack to Corliss Lamont (3/7/1938), Dewey Correspondence.

24. “John Dewey Rebukes Those Liberals Who Will Not Look Into Facts," The New Leader (May 15, 1937), 181 - 182. Dewey wrote to Malcolm Cowley: "But with Russia and the Soviets so constantly held up for us as a model for America, I think it is necessary for the clarification of American political thought and action that an honest effort be made to get at the truth." John Dewey to Malcolm Cowley (6/12/1937). Dewey Correspondence.

25. "Want Russia Recognized," New York Times (23 March 1933), 37.

26. Franz Boas to Mildred Leibman (4/15/1937), PCFBAPS.

27. University Federation for Democracy and Intellectual Freedom, "Open Letter on Culture and Democracy in Spain" (5/2/1938), PCFBAPS; "Rebels Criticized for Closing Schools," New York Times (8 May 1938), 1; John Dewey, "Aid for the Spanish Government," Christian Century (March, 1937), 292 - 93.

28. Franz Boas to John Dewey (2/3/1937), PCFBAS.

29. "Papa Boas - Great Scientist Who Mobilizes Culture for Political Liberty, Daily Worker (16 July 1938), 4.

30. “Dr. Boas, 78, Quits in a Sick World," New York Times (11 May 1936), 26.

31. "Nazi Conception of Science Scored," New York Times (11 December 1938), 30; “Scientists Open Drive for Freedom," New York Times (24 January 1929), 21; see Kuznick, Beyond the Laboratory, 190.

32. "Nazi Conception of Science Scored," New York Times (11 December 1938), 30.

33. “Threat to Nation Seen By Educators," New York Times (24 April 1939), 34.

34. “Boas Joins Union Led by Reds," New York Times (11 December 1938), 17.

35. Franz Boas to Clyde Miller (1/9/1939), PCFBAPS. Contemporaneously, John Childs and Louis Hacker quit the Teachers Union. "Four Prominent Columbia Professors Quit Teachers Union, Score Stalinists," New Republic (7 January 1939), 2.

36. Franz Boas to Clyde Miller (1/13/1939), PCFBAPS.

37. Christopher Phelps, Young Sidney Hook (Ithaca: Cornell University Press, 1997), 202.

38. Franz Boas to Harry Schneiderman(5/15/1939), PCFBAPS. Schneiderman was an American Jewish Committee Board member.

39. Kuznick, Beyond the Laboratory, 216. Kuznick argued that John Dewey, not Sidney Hook, was the anti-communist liberal considered to be the most dangerous threat to the ACDIF.

40. Franz Boas to Belle Northrup (5/9/1939), PCFBAPS. 
41. “Dr. Hartman out of Teachers Union,” New York Times (25 May 1939), 4.

42. John Dewey to Franz Boas (5/15/1939), Dewey Correspondence.

43. Hook, Out of Step, 258.

44. Sidney Hook to Franz Boas (5/26/1939), PCFBAPS.

45. "New Group Fights Any Freedom Curb," New York Times (15 May 1939), 13; Franz Boas, "Cultural Freedom Sought," New York Times (17 May 1939), 22c; Sidney Hook, "All Totalitarianism Opposed," New York Times (17 May 1939), 22c; John Dewey to Franz Boas (5/27/1939), Dewey Correspondence.

46. John Dewey to Sidney Hook (5/27/19339), Dewey Correspondence.

47. Hook, Out of Step, 257-59.

48. "Liberty and Common Sense," New Republic (May 31, 1939), 84; Dewey, "The Committee for Cultural Freedom," New Republic (June 14, 1939), 161-62.

49. "Call to All Active Supporters of Democracy and Peace," Daily Worker (14 August 1939), 1.

50. Ferdinand Lundberg, "Stalinists Smear Cultural Committee as 'Fascists"' The New Leader (July 29, 1939), 5. Two members of the American Committee for Democracy and Intellectual Freedom, Walter Cannon (Harvard physiologist) and Wesley Mitchell (Columbia economist) signed the CCF declaration. Walter Cannon was President of the American Association for the Advancement of Science in 1939 and Mitchell served in that capacity in 1940. The Daily Worker (31 December 1938) praised Cannon's election prematurely. After citing the Boas-sponsored National Emergency Committee as "under outright Communist control," Cannon observed that the Communists "have defended Russian terrorism through thick and thin, and are open apologists for the brutal attack on Finland and the connivance of Stalin with Hitler and Hitler's perpetuation of cruelty." Walter Cannon to Harlow Shapley (4/30/1940), Harlow Shapley Correspondence, Harvard Observatory Records. See Kuznick, Beyond the Laboratory, 220 - 25. Wesley Mitchell continued to rubber stamp Boas' political initiatives.

51. Franz Boas to the Initiating Committee of a Call to All Active Supporters of Democracy and Peace (7/20/1939), PCFBAPS.

52. Franz Boas to the Initiating Committee of a Call to All Active Supporters of Democracy and Peace (7/20/1939), PCFBAPS.

53. Nation (September 2, 1931), 231.

54. Harry Schneiderman to Franz Boas (10/14/1939), PCFBAPS.

55. Franz Boas to Wesley Mitchell (3/11/1941), PCFBAPS.

56. Franz Boas to Miles Goldberg (4/15/1940), PCFBAPS.

57. Franz Boas to Wesley Mitchell (3/11/1941), PCFBAPS.

58. The meeting between Hook, Dewey and Boas was described as "friendly and cooperative." Hook later wrote that Boas was rude and discourteous to Dewey. Minutes of the Committee on Plans and Organization, CCF (June 26, 1939), Tamiment Library, New York University, New York City; Hook, Out of Step, 258.

59. M.I. Finkelstein to Dr. Abraham Lefkowitz (10/21/1939), PCFBAPS.

60. Minutes of the Committee on Plans and Organization, CCF (October 1, 1939), Tamiment Library, New York University.

61. Kuznick, Beyond the Laboratory, 221.

62. Kutulas, The Long War, 167.

63. Minutes of the Meeting of the Plans and Organization Committee (September 11, 1939), Tamiment Library, New York University. 
64. “Open Letter to the LAW," Partisan Review (1939), 127; Eugene Lyons, The Red Decade (New York: Bobbs-Merrill Co., 1941), 320.

65.John Dewey to Franz Boas (10/ 25/1939), Dewey Correspondence.

66.Franz Boas to John Dewey (11/6/1939), PCFBAPS.

67.John Dewey to Franz Boas (11/9/1939), PCFBAPS; For a more comprehensive examination of Boas' censorship efforts, see Gary Bullert, "Franz Boas as Citizen-Scientist," Journal of Social, Political and Economic Studies (Summer, 2009), 217-218.

68. John Dewey to Frank Trager(11/16/1939), Dewey Correspondence; John Dewey to Sidney Hook (11/16/1939), Dewey Correspondence.

69. John Dewey to Evelyn Scott (11/17/1939), Dewey Correspondence.

70. Sidney Hook, "The Art of Crypto-Stalinism," The New Leader (November 18, 1939), 5.

71. Sidney Hook to Roger Baldwin (10/18/1939), Dewey Correspondence; John Dewey to Roger Baldwin (9/27/1939), Dewey Correspondence.

72. Hook, "The Fight for Civil Liberties Can Balk 'Totalitarianites"' The New Leader (October 7, 1939), 5

73. Executive Committee Minutes, CCF (April 15, 1940), 2, Tamiment Library, New York University.

74. “Liberty Union Urged to End Ban on Reds," New York Times (18 March 1940), 17.

75. Roger Baldwin to Francis McKee (3/8/1941), PCFBAPS. In a letter to Walter Cannon (April 24, 1942), Baldwin stated, "there is no doubt that the Committee for Democracy and Intellectual Freedom has a strong pro-Communist slant and that its' paid secretary, Finkelstein, is either a member of the Communist Party or a close associate. The honorary chairman, Prof. Franz Boas of Columbia, is a well-known Communist supporter, who, despite his age is personally active in support of movements initiated by the Communist Party." Kuznick, Beyond the Laboratory, 337.

76. Ephraim Schwartzman to Franz Boas (10/10/1939), Boas to Schwartzman (10/23/1939), PCFBAPS.

77. Kuznick, Beyond the Laboratory, 224.

78. “500 Scientists Ask U.S. to Avoid War," New York Times (20 May 1940), 4. This prompted a strong reaction as Albert Einstein and several other scientists repudiated the document. "Scholars Assail Peace Manifesto," New York Times (22 May 1940), 22; Walter Cannon was elected as the first President of the AASW "without his knowledge or consent" but permitted himself to be appropriated anyway. He renounced the peace declaration two days after its announcement. Kuznick, Beyond the Laboratory, 305; see Franz Boas to Bella Dodd (7/19/1940), PCFBAPS.

79. Franz Boas to American Association of Scientific Workers (5/8/1940), PCFBAPS.

80. Albert E. Kahn to Franz Boas (4/26/1940), PCFBAPS.

81. Dewey Chronology, Center for Dewey Studies, Carbondale, Illinois.

82. John Dewey to Franz Boas (2/8/1940), Dewey Correspondence.

83. Franz Boas to John Dewey (2/10/1940), Dewey Correspondence.

84. John Dewey to Franz Boas (2/21/1940), Dewey Correspondence.

85. CCF Bulletin (February 12, 1940), Tamiment Library, New York City.

86. "Investigating Education," New York Times (6 May 1940), 12.

87. Kutulas, The Long War, 198.

88. "Stalinist Outposts in the United States," Tamiment Library, New York University. The Report can also be located in the Franz Boas correspondence. 
89. “1,500 U.S. Teachers Red, Dr. Dodd Says,” New York Times (11 September 1952): 1. Bella Dodd's remarkable political odyssey is located in her School of Darkness (New York: Kennedy, 1954).

90. Clarence Taylor, Reds at the Blackboard: Communism, Civil Rights, and the New York Teachers Union (New York: Columbia University Press, 2009), 224.

91. Dashiell Hammett to Franz Boas (1/11/1940); Franz Boas to Dashiell Hammett $(1 / 15 / 1940)$, PCFBAPS.

92. Franz Boas to Bertha Foss, National Emergency Committee (10/29/1939), PCFBAPS; Franz Boas to Helen McFarlane (10/18/1940), PCFBAPS.

93. Franz Boas to Alice Dodge (8/5/1940), PCFBAPS.

94. Carl Becker to Franz Boas (11/25/1941), PCFBAPS.

95. "Hundreds of Reds in Teachers Union," New York Times (5 May 1941), 27. John Diggins claimed that Reinhold Niebuhr tried to solicit Dewey in 1944 to rejoin the Committee for Cultural Freedom but Dewey declined because he thought that too much attention was afforded to the communist issue. Diggins misread the letter in a variety of ways - the most obvious being that Niebuhr's letter had nothing to do with the Committee for Cultural Freedom but the Council for a Democratic Germany, an organization that Dewey joined. This reinforced another fallacy, Diggins stated, "Nor did Dewey become, as did Hook, an embittered anticommunist." Dewey was as militant an anticommunist as Hook. When the American Committee for Cultural Freedom assembled, Dewey served as honorary chairman. John Diggins, The Promise of Pragmatism (Chicago: University of Chicago Press, 1994), 400; "Council for Democratic Germany Formed by Refugee Leaders Here," New York Times (5 May 1944), 10; Reinhold Niebuhr to John Dewey(5/22/1941), Sidney Hook Papers, Hoover Institute, Stanford, California

96. John Dewey and Horace Kallen ed., The Bertrand Russell Case (New York: Viking Press, 1941), 227 pp.

97. “Inquiry Assailed at Teachers' Rally," New York Times (9 December 1941), 25.

98. "Staff with Gideonse in Demanding Investigations," New York Times (15 January 1940), 17.

99. "City College Head Bans 'Party Line", New York Times (14 March 1941), 23; "25 Educators Back Union Ouster,” New York Times (28 February 19410, 24.

100. The Communist (May, 1937) cited from Out of Step, 499; "40 Reds in City College Staff, Teaching Slanted Witness Says," New York Times (7 March 1941), 1; “Witnesses Charge Threats by Reds," New York Times (15 March 1941), 1

101. Taylor, Reds at the Blackboard, 53; Philip Taft, United They Teach, 89.

102. Robert Morris, No Wonder We Are Losing (New York: The Bookmailer, 1955), 19.

103. Reds at the Blackboard, 145.

104. Hook, Out of Step, 503.

105. Ferdinand Lundberg, "The Record of P.M.”, The New Leader (June 20, 1942 ), 15.

106. Taylor, Reds at the Blackboard, 70

107. M.J. Heale, American Anti-Communism: Combating the Enemy Within, 1830 -1970 (Baltimore: John Hopkins University Press, 1990), 129; "Coudert Defends His Red Inquiry," New York Times (26 September 1941), 25.

108. Morris, Why We Are Losing, 7.

109. Ellen Schrecker, No Ivory Tower, 76 - 79.

110. Senator Coudert to Franz Boas (9/30/1940; Franz Boas to Harry Gideonse(12/41941); Harry Gideonse to Franz Boas(12/11/1941); Franz Boas to Harry Gideonse(12/15/1941), all PCFBAPS. 
111. Franz Boas to Charles Hendley(4/12/1940), PCFBAPS.

112. J.R. Oppenheimer to F.R. Coudert(10/13/1941), PCFBAPS; Richard Polenberg, In the Matter of J. Robert Oppenheimer: the Security Clearance Setting (Ithaca: Cornell University Press, 2002), 7.

113. Harry Gideonse to the Brooklyn College Faculty (11/28/1941), PCFBAPS.

114. Ira Hirschman to Franz Boas (12/311941), PCFBAPS.

115. "City College Teacher an Active Red for 5 Years He Admits Voluntarily," New York Times (6 March 1941), 23; see Lebenstein, "Purging the Reds," 116.

116. Cited from Paul Kengor, Dupes (Wilmington: ISI Books, 2010), 24. Senator Coudert explained: "Our committee has called to public account only those teachers, who, as the evidence showed, were engaged in a secret, conspiratorial activity of a political nature, and testified falsely about such activities when called to account. ... It is obvious that the public can, and should tolerate teachers who hold extreme views, but do not abuse their positions of trust in the educational system." "Coudert Defends His Red Inquiry," New York Times (26 September 1941), 25. Proponents of the Communist teachers as martyrs template, should be reminded of the Fred Beal case. Beal was a Communist Party member who was convicted of murder in the Gastonia strike but escaped to the Soviet Union. After three years, he returned to the United States disillusioned with Stalinism. He was apprehended as an escapee. When he wrote a book critical of the Soviet Union, the Teachers Union promptly removed its support for Beal's parole. Taylor, Reds at the Blackboard, 64. Beal languished in prison for an additional four years. John Dewey worked for the release of Beal. See Dewey, "Freedom for Fred E. Beal Committee," The New Leader (17 June 1939), 2.

117. Ordway Tead to Franz Boas (4/24/1941), PCFBAPS. In addition omitting these provisions, Stephen Lebenstein's analysis of the Rapp-Coudert Committee excluded the following: 1) no mention of the overwhelming faculty support at Brooklyn College and CCNY for cooperating with the investigation, 2) Communist Party files revealing their large membership and dominance of the Teachers Union, 3) Bella Dodd's congressional testimony, 4) the New York Times endorsement of the Committee's work, 5) admissions by defendants, like Max Yergen, that they were Party members all along, 6) no acknowledgment that the Communist Party scripted the whole defense strategy. See Stephen Leberstein, "Purging the Profs: The Rapp-Coudert Committee in New York, 1940-42," in Michael E. Brown, ed. New Studies in U.S. Communism (New York: Monthly Review Press, 1993), 91-122.

118. "Accused Teachers Denounce Inquiry," New York Times (10 March 1941), 1; Hook, Out of

Step, 258.

119. ACDIF, "A Public Statement,"(July 28,1941), PCFBAPS, "Reds Here Shift on War," New York Times (27 July 1941), 16.

120. “A.P.M. Drops 'Peace’ As War Hits Soviets,” New York Times (28 July 1941), 5.

121. Harry Gideonse to Franz Boas (10/22/1941), PCFBAPS.

122. Franz Boas to Joseph Davies (7/21/1941), PCFBAPS.

123. John Dewey, "Russia's Position," New York Times (11 January 1942), E7; Sidney Hook, "Russian Military Successes Do Not Whitewash Crimes at Home," The New Leader (June 7, 1942), 5.

124. “Davies 'Mission to Moscow' Praised at Rally," New York Times (21 May 1943), 4. See "V.F.W. Aide Defends 'Mission to Moscow:' Fight on Film Is Attributed to 'Subversive Influence," New York Times (19 May 1943), 8. 
125. See John Earl Haynes, Harvey Klehr, and Alexander Vassiliev, Spies (New Haven: Yale University Press, 2009), 472.

126. John Dewey to George Lundberg (2/10/1942), Dewey Correspondence.

127. Boas to Convention Delegates of American Federation of Teachers (7/31/1941), PCFBAPS.

128. “Teachers Uphold Ouster of 'Reds," New York Times (24 August 1941), 18.

129. "A Plea of Guilty," New York Times (5 June 1941), 22; Sidney Hook, Out of Step, 253.

130. “The Coudert Report," New York Times (24 April 1942), 16.

131. "Hundreds of Reds in Teachers Union, New York Times (5 May 1941), 23; "1,500 U.S. Teachers Red, Dr. Dodd Claims," New York Times (9 September 1952), 1.

132. Irving Kristol, "Civil Liberties - 1952, a Study in Confusion," Commentary (March, 1952): $228-236$.

133. For example, see Kutulas, The Long War, 165; Kuznick, Beyond the Laboratory, 168. In his generally fair-minded account, Richard Gid Powers also accused Hook of taunting and humiliating the pro-Stalinist Left by insisting that the Left should banish Communist Party members from their ranks. Both Dewey and Hook were convinced that the Communist-sympathy label gravely damaged the political discourse in the United States by giving all dissent the stigma of treason. Richard Gid Powers, Not Without Honor (New York: The Free Press, 1995), 58-59.

134. For Reinhold Niebuhr's critique of scientific rationalism, see Gary Bullert, The Politics of John Dewey (Buffalo: Prometheus Books, 1983), 182 - 186.

135. See Kuznick, "Franz Boas Mobilizes Scientists against Fascism," in Beyond the Laboratory, $171-95$.

136. Kutulas, The Long War, 158

137. Corliss Lamont to John Dewey (4/24/1940), Dewey Correspondence.

138. Sidney Hook, Political Power and Personal Freedom (New York: Criterion Books, 1959), 187.

139. Hook, Political Power and Personal Freedom, 188-93.

140. Franz Boas to Frank Bohn (1/29/1940), PCFBAPS.

141. Franz Boas FBI file (61-7559-7483), Hoover Memorandum for the Attorney General (April 4, 1940)

142. Hook, Political Power and Personal Freedom, 194.

143. Hook, Out of Step, 257 - 259.

144. Taylor, Reds at the Blackboard, 141.

145. Schrecker, No Ivory Tower, 42 - 46. The Morris Schappes case is one relevant example of collaboration between Communist faculty and students. In 1936 when Schappes was initially dismissed, the American Student Union held protests and collected 1,500 signatures demanding his reinstatement. They succeeded. Over several years, Franz Boas sponsored numerous Communist student events and organizations. See Franz Boas to Agnes Reynolds, American Student Union (3/14/1940); Franz Boas to Sol Geffner, Student Council Peace Committee, CCNY (3/19/1940), PCFBAPS. If Schrecker had researched the letterheads and events of Communist Party student organizations, she would not have advanced the incredible claim of minimal or no collaboration between Communist Party students and faculty. Both Sidney Hook and Theodore Draper disposed of the myth of the Communist professor in masterful reviews of Schrecker's book. See Sidney Hook, Convictions (Buffalo: Prometheus Books, 1990), 276-98; Theodore Draper, “The Class Struggle," New Republic (January 26, 1987), 29-37. 
146. Schrecker, No Ivory Tower, 57.

147. Schrecker, No Ivory Tower, 82.

148. See “The Struggle for Free Speech at CCNY, 1931-42," http://www.vnyicuny.edu/ gutter/panels/panel/22.html.

149. Colby College Magazine (Spring, 2000).

150. Ronald Radosh, "Arthur Schlesinger and Sidney Hook," (December 12, 2002) republished in www.frontpage.com. See Christopher Phelps, Young Sidney Hook, 218-38; Robert Westbrook, "Stream of Contentiousness," Nation (May 27, 1987), 726 - 30; Robert Westbrook, John Dewey and American Democracy (Ithaca: Cornell University Press, 1991), 494. On the effort to minimalize the distance between Dewey and Hook, see Gary Bullert, "From Dewey to Hook: World War II and the Crisis of Democracy," in Matthew Cotter, ed., Sidney Hook Reconsidered (Buffalo: Prometheus Books, 2004), 203-224. For detailed discussion of the Communists as Teachers Controversy, see Miles Eldridge, "Dewey's Bulldog and the Eclipse of Pragmatism," 129-146 in Sidney Hook Reconsidered. An additional example of the leftist portrayal of Dewey as a "populist-communitarian" is Harry Boyte," A Different Kind of Politics: John Dewey and the Meaning of Citizenship in the Twenty-First Century," Dewey Lecture at the University of Michigan, November1, 2002, at www.cpn.org/crm/contemporary/different.html. Boyte served as a member of the Midwest Academy and in 2008, was an advisor to the Obama Presidential Campaign.

151. John Dewey to Bertha Afleck (2/19/1940), PCFBAPS.I

Gary B. Bullert is at Columbia Basin College.

E-mail: gbullert@columbiabasin.edu 